\title{
From Periphery to Centre: Local Government and the Emergence of Universal Healthcare in Indonesia
}

\section{DIEGO FOSSATI}

While the debate on universal healthcare coverage (UHC) often focuses on policy prescription and technical issues, the expansion of access to healthcare in developing countries is an eminently political process. This article analyzes the historical background of the adoption of UHC in Indonesia to articulate two intertwined arguments. First, in decentralized young democracies such as Indonesia, local government can play an important role in health policy by experimenting with innovative health insurance schemes. Although such activism may widen subnational inequalities, it can also contribute to the adoption of UHC by increasing the salience of health reform and by allowing policy learning. Second, institutional developments such as decentralization and the introduction of local direct elections can have a substantial impact on incentives for political elites to provide broad-based social services. This article discusses the relevance of these findings for the comparative literature on UHC and social policy in low and middle-income countries.

Keywords: Indonesia, healthcare, democratization, decentralization, policy diffusion.

Diego Fossati is a Research Fellow at the Griffith Asia Institute, Griffith University. Postal address: Griffith Asia Institute, 170 Kessels Road, N16 Room 1.75, Nathan QLD 4111, Australia; email: d.fossati@griffith. edu.au. 
Access to healthcare has long been a topical issue in developing countries, in which healthcare services are often underprovided, of low quality and too costly for a large proportion of the population. In recent years, as an increasing number of low and middle-income countries have taken significant steps to address this issue, the idea of universal health coverage (UHC) has gained traction among policymakers, advocates and citizens. For its proponents, UHC is a crucial tool to balance inequities in access to healthcare in developing countries, as it ensures the removal of financial barriers and reduces overall healthcare costs by pooling a large base of users. Key international institutions such as the World Health Organization (WHO) and the United Nations (UN) have embraced the UHC reform agenda, repeatedly referring to access to healthcare as a human right, and to UHC as a requisite to fulfill this right in developing countries. ${ }^{1}$

The literature on UHC has long been dominated by policyoriented approaches and health economics. Studies of UHC reform typically tackle some technical aspect of policy design; for example, how best to finance UHC plans or gradually expand health system capacity, or they assess policy impacts on outcomes such as healthcare utilization, out-of-pocket expenditures and health indicators. ${ }^{2}$ The result is that this literature focuses on policy prescription rather than explanation of reform adoption, and that it often presents a view of UHC as a consensual, technical project. ${ }^{3}$ Yet reforming health systems to include a large number of previously excluded citizens is, of course, an eminently political and potentially contentious issue, as it is a question of economic redistribution and because it requires substantial fiscal resources.

While most studies of UHC do not delve into the politics of reform adoption, some exceptions, and a larger comparative literature on social policy in developing countries, have identified a few key determinants of social policy expansion. A first group of explanations studies the role of leftist political parties in expanding health coverage. ${ }^{4}$ From this perspective, UHC policies are more likely to be adopted when ruling political elites are supportive of economic redistribution because of their partisan and ideological orientations. While this framework was developed from the experience of welfare state expansion in the West, some support has been found for other world regions. ${ }^{5}$ A second approach focuses on voter-politician linkages in the developing world, and argues that the clientelistic relationships that often dominate politics in new democracies impede the provision of broad-based social services. ${ }^{6}$ In many young democracies, leftist 
programmatic parties are absent, and clientelistic politics entails the provision of selective benefits conditional on political support rather than universalistic social programmes. Finally, a third perspective analyzes institutional change, and regime change in particular. From this angle, the establishment of democratic institutions is a key determinant of the expansion of social safety nets in low and middleincome countries. ${ }^{7}$ Democratization often increases opportunities for political participation and contestation, and increased accountability can lead to the adoption of polices that more closely mirror the preferences of a large share of the electorate. ${ }^{8}$

A common feature of studies on the determinants of UHC emergence in developing countries is that they all focus on national governments. To be sure, this is a sensible research strategy, as the huge resources needed for such transformative social programmes can typically only be mustered by national authorities, especially in developing countries where institutional capacity at the local level is often weak. However, in this article I adopt a different perspective, one that focuses on the role of local government in supporting and facilitating UHC in low and middle-income countries. I study the case of health politics in Indonesia - a country that is currently implementing a road map to reach UHC in 2019 - to show that local government can be an important and active player in the reform process, rather than just an implementer of policies designed by national policymakers. In Indonesia, a decentralized and highly diverse young democracy, local governments acquired substantial policy powers with decentralization reforms implemented shortly after the fall of President Suharto's authoritarian New Order regime in 1998. Interestingly, despite the dominance of patronage politics and clientelism in many Indonesian regions, ${ }^{9}$ some districts and provinces used these new powers to experiment with various innovative health policies, and some of them reached UHC within their jurisdictions as early as 2009. These developments helped put the issue of UHC on the agenda of national policymakers, and provided a range of policy templates and case histories that informed successive national programmes. This suggests that local governments may be important agents of change in large, decentralized developing countries such as Indonesia.

The remainder of this article proceeds as follows. I first review the literature on health reform in low and middle-income countries, thereby situating the Indonesian case in the comparative literature on social policy in the developing world. I then introduce the empirical setting with a brief history of healthcare reform in 
Indonesia, a process of gradual extension of health benefits to increasingly large sectors of the population. Following this, I switch the focus to local government, first by tracing the process of its involvement and activism in reforming Indonesia's health systems, and then by analyzing two key factors that allowed such activism. First, decentralization reforms provided the institutional and fiscal foundations for a more assertive role of local government in health policy, and transformed the politics of health into an arena where national and local governments interact to shape policy outcomes. Second, decentralization and democratization changed the incentives for local politicians to provide broad-based social services. I conclude the paper by discussing the limitations and the significance of the findings.

\section{Explaining Healthcare Reform in the Developing World}

In many low and middle-income countries, access to healthcare is a highly salient issue. At some point in their history, developing countries in which economic growth underpins sustained socioeconomic development face the crucial issue of reforming their health systems to include large numbers of previously excluded users. The timing of the adoption of such reforms, however, has varied considerably, and so have the health policy outcomes in terms of social groups included in the system, health services covered, financing mechanisms, the role of the private sector and so forth. Such cross-country variation has provided the empirical background for a burgeoning comparative literature exploring various factors related to the adoption and the design of redistributive politics such as healthcare reform.

A first explanation in the literature - informed by the trajectory of welfare state development in the West - points to the role of the political left to explain the emergence of redistributive social policies. ${ }^{10}$ Leftist parties with an ideological inclination for pro-poor policies are stronger in some countries than in others, and this could explain the variation in outcomes such as reform adoption and the generosity and inclusiveness of the benefits provided. Classbased mobilization and "left power", or the degree to which leftist political actors are prominent, have been shown to be an important determinant of redistribution and social policy in the developing world, for example in Latin America and South Asia. ${ }^{11}$ Related work on Latin American politics has refined this framework by investigating differences across leftist parties, showing that factors such as their ideology, degree of institutionalization and linkages to 
key stakeholders in society are crucial in explaining social policy outcomes and the emergence of UHC in particular. ${ }^{12}$ As for Indonesia, however, explanations based on the power of the left are unable to account for the substantial expansion of social security programmes observed in recent years, as leftist parties have been absent from the political landscape since the brutal repression of the political left in 1965-66, and because labour unions remain weak. ${ }^{13}$

Second, in many low- and middle-income countries, politics is dominated by clientelistic relationships, and such linkages between politicians and voters provide informal social safety nets. ${ }^{14}$ From this perspective, the incidence of clientelism may be a key reason why government fails to provide broad-based social services such as universal health insurance policies. ${ }^{15}$ When patronage is an effective strategy to win votes, politicians have little incentive to gain a reputation as "reformers", ${ }^{16}$ and are thus reluctant to adopt policies that benefit a large proportion of the population. For example, Kurt Weyland uses the case of Brazil in the 1990s to argue that entrenched clientelistic networks impeded the emergence of the comprehensive healthcare reform advocated by grassroots organizations. ${ }^{17}$ Some research has also observed that the demand for clientelistic relationships may be higher in regions with high levels of poverty, as voters respond more strongly to the provision of selective benefits and electoral strategies based on materialistic exchanges. ${ }^{18}$ Again, the Indonesian case is hard to explain using this analytical approach. While there is a deep-rooted ideological cleavage between secularist and Islamic parties in Indonesia, ${ }^{19}$ this distinction does not correspond to differences in social policy platforms across parties. More broadly, identifying "programmatic" parties in Indonesia is problematic, as all parties alike are known to engage extensively in clientelistic practices, corruption and patronage politics. ${ }^{20}$

A third approach focuses on the connection between institutions and policy, and in particular on the effect of democratization on social policy outcomes. ${ }^{21}$ With some exceptions, research in this tradition has identified the beneficial effects of democratization on the provision of social services, showing that democratic institutions are associated with higher levels of health and social welfare. ${ }^{22}$ As for the specific mechanisms through which democratization facilitates the expansion of welfare state institutions, the literature offers different perspectives. Some scholars emphasize the importance of participation and bottom-up pressures, ${ }^{23}$ while others argue that incentives for political elites are the key factor, ${ }^{24}$ and yet some others 
focus on specific actors such as advocacy and policy networks. ${ }^{25}$ Although some have observed the nexus between democratization and policy is more complex than commonly assumed, ${ }^{26}$ this approach has found empirical support in Asian cases such as South Korea and Taiwan. ${ }^{27}$

At first glance, Indonesia appears as a typical example of the connection between democratization and increased health policy spending, as major initiatives to expand access to healthcare were launched only a few years after the downfall of the New Order regime. ${ }^{28}$ However, regime change alone is not sufficient to account for the process through which UHC emerged as a key policy goal in Indonesia. A distinctive feature of democratization in Indonesia is that the breakdown of authoritarianism has been coupled with a radical project of decentralization, in which local governments have acquired substantial policy powers in various fields, including healthcare. While foundational, large-scale national programmes were instrumental in expanding access to healthcare in democratic Indonesia, decentralized governance has allowed Indonesian regions to play an important role in this process. First, local governments were pivotal in implementing national health insurance programmes. Second, some districts, cities and provinces used their newly acquired prerogatives to pioneer policies offering free healthcare to low-income citizens and, in some cases, to all residents in their jurisdiction. I document in the next sections how such developments in Indonesian regions informed policy plans for UHC at the national level, and more broadly how decentralization reforms changed policymaking and centre-periphery relations in this policy area.

\section{Indonesia's Healthcare: From Selective Benefits to Universalism}

Indonesia is currently following an ambitious plan to build a more inclusive and effective health system. In early 2014, as the end of the Yudhoyono presidency was approaching, the national government launched a programme called Jaminan Kesehatan Nasional (JKS), or National Health Insurance. This programme is gradually expanding access to healthcare among Indonesians through a system that provides subsidized health insurance scheme for the very poor and a contributory scheme for the rest, and it is set to achieve UHC in 2019 - at which point Indonesia should become the largest single-payer healthcare system in the world. As with many low and middle-income countries, the adoption of UHC policies in Indonesia is the result of a long historical process through which increasingly 
large segments of the population have been gradually incorporated into the health system.

The foundational policies in this area were designed during the years of Guided Democracy under President Sukarno, with the introduction of two social security programmes for civil servants in 1963 and their extension to workers in the private formal sector in 1964. ${ }^{29}$ However, it was during the New Order that these programmes were revamped and consolidated at various stages. A major restructuring of social policy took place in the mid-1990s, when several existing schemes were merged into JAMSOSTEK, a social security programme that included coverage for some healthcare expenses, work accidents, a savings programme and death benefits. While these schemes included only a small share of the Indonesian population - namely those employed in the civil service, the military and the formal sector - lower-income Indonesians benefited from other health policies implemented under authoritarianism. Perhaps most importantly, the number of Puskesmas, local clinics used mostly by the poor and providing basic healthcare services at low cost, increased rapidly from about 1,000 in 1969 to more than 6,000 in 1991, according to data from the Ministry of Health. ${ }^{30}$ The development of this network of clinics was particularly visible in rural areas and poorer regions, which benefited disproportionately from an infrastructure-building programme called INPRES Kesehatan. ${ }^{31}$ The launching in the mid1970s of JPKM (Jaminan Pemeliharaan Kesehatan Masyarakat), a programme to support access to healthcare for the indigent, is a further example of how social security policies under authoritarianism targeted low-income citizens, although the coverage of this programme was very limited. ${ }^{32}$

The 1997-98 Asian Financial Crisis represented a turning point for health insurance and social security programmes in Indonesia, as it exposed the vulnerability of many households to economic shocks. The Puskesmas network was hit particularly hard by cuts in social spending, which deteriorated the quality of service provision, and the economic crisis caused a sharp decline in health services utilization. ${ }^{33}$ In response to these dramatic developments, national policymakers designed, in cooperation with the World Bank, a new social security package called JPS (Jaring Pengaman Sosial), which included a bundle of poverty alleviation initiatives and a health card to grant indigents free access to healthcare. ${ }^{34}$ While the JPS health scheme was limited in scope and suffered from important 
implementation problems, it provided a blueprint for designing health insurance programmes as measures to alleviate poverty and inequality. Indeed, a radical expansion of health insurance for the poor took place only a few years later, in 2005, with the launch of Askeskin, a programme offering free health insurance to about 60 million low-income Indonesians. Patients covered by this programme - expanded and renamed as Jamkesmas (Jaminan Kesehatan Masyarakat) in 2007 - could receive a range of basic in- and outpatient treatments in Puskesmas and public hospitals by presenting their membership card. The implementation of Jamkesmas suffered from some crucial limitations such as low awareness of benefits among beneficiaries, and poor targeting and insufficient quotas in many districts, although there is strong evidence that the programme was instrumental in increasing access to healthcare among low-income Indonesians. ${ }^{35}$

The implementation of large-scale social programmes such as Askeskin and Jamkesmas occurred while Indonesia was laying the foundations for a thorough overhaul of its social security policies. Law 40/2004, in particular, outlined the key goal of a National Social Security System (SJSN) that would merge all the existing social insurance programmes into a single, national, universal scheme providing all Indonesians with retirement pension, health insurance, workplace accident insurance and life insurance, benefits that are described as "rights" in various articles of the law. ${ }^{36}$ The implications of this profound restructuring of Indonesian social policy for health insurance programmes were substantial. ${ }^{37}$ The new National Health Insurance scheme, JKN or Jaminan Kesehatan Nasional, mandates that all existing national and local government health insurance programmes be merged into the new programme, and that UHC be achieved by the end of 2019 through a gradual expansion of existing schemes that started in January 2014. In short, the approach to designing health insurance programmes in Indonesia has changed radically over the past five decades. Initially conceived as employment benefits for small sectors of the population, health insurance programmes were incorporated during the New Order into a broader social security agenda. With democratization, large-scale health insurance programmes for the poor became key tools in poverty alleviation and development policy, and later, with the introduction of UHC as a major policy goal, access to healthcare was increasingly conceptualized as a social right for all Indonesians. 


\section{Health Policy in the Regions}

Local governments have historically played an important role in Indonesian health policy. For example, village heads were important actors in the implementation of the already mentioned JPKM programme, as they had substantial autonomy on how to allocate the programme's funds. However, during the New Order, local governments had a limited scope of action in this policy area and, more broadly, in governance and development. On the one hand, local governments and villages in particular were tightly controlled by the central government with the intention to cripple opposition and political activism, ${ }^{38}$ and development initiatives at the village level were often supervised by the military and other government agencies. On the other hand, resources available to local governments were very limited, and local administrators had to observe a wide range of restrictions for their allocation. As for health policy in particular, another factor limiting the involvement of local governments was that due to low demand for healthcare services and the prevalence of traditional healing practices, health projects were often not as salient as other development initiatives such as infrastructure building. ${ }^{39}$

The implementation of decentralization reforms at the beginning of 2001 changed this policy landscape substantially by giving more power to local governments, and to districts in particular. For health policy and the emergence of UHC, the otonomi daerah (regional autonomy) project entailed two important developments. The first is that increased policy autonomy at the district level sparked a wave of policy experimentation and innovation in health policy. To be sure, the prevailing mode of citizen-politician relations in many Indonesian regions is still based on patronage politics, and local politics is often uncompetitive and dominated by predatory elites, as shown by early research on the outcomes of decentralization. ${ }^{40}$ Yet despite such limitations, local governments in decentralized Indonesia have proven able to design innovative, reformist policies in areas such as primary education, procurement, sanitation, and participatory governance, with innovation in health policy in particular being identified as a key feature of Indonesian decentralization. ${ }^{41}$

Starting from the early 2000s, a limited number of districts and cities implemented health insurance schemes with the goal of expanding access to healthcare substantially, especially among the poor. According to a study funded by the Indonesian Ministry of 
Health published in 2008, a total of twenty-four districts and cities had been implementing their own health insurance programmes for at least one year in 2007, and seventy-two others had already approved similar initiatives. ${ }^{42}$ While these schemes, known as Jamkesda or Jaminan Kesehatan Daerah (Regional Health Insurance), varied substantially in their coverage, financing and implementation,,$^{43}$ they all aimed at providing free or highly subsidized healthcare services to at least some residents, typically poor and often near-poor segments of the population. In some cases, however, local governments laid out more ambitious plans to reach UHC within their jurisdiction. A well-known example is the case of Jembrana in Bali, where the local government implemented a health insurance scheme providing all residents with free general care and some dental and specialist healthcare services that could be delivered both by public and private service providers. ${ }^{44}$ Providing conclusive evidence that such local-level developments were crucial in informing national policy is arduous. However, it should be emphasized that early Jamkesda programmes preceded plans for the implementation of Askeskin, the first large-scale national health insurance programme, and that the launching of Askeskin in 2005 was perceived by some commentators and local government officials as being a reaction to local government activism. ${ }^{45}$ This suggests that, to some extent, local health insurance programmes have facilitated the emergence of UHC in Indonesia by helping to put the issue of equity in access to healthcare on the national political agenda.

The second related development in health policy following the implementation of decentralization reforms is that new subnational inequalities in access to healthcare began to emerge. After the phase of policy innovation described above, Jamkesda programmes proliferated rapidly across the country. Comprehensive information on local regulations is absent, but available data indicates a largescale process of policy diffusion through which almost all districts adopted at least some form of Jamkesda between 2007 and 2013, the year preceding the launch of the JKN. A survey of local governments fielded in 2011 by the Center for Health Insurance Financing of the Indonesian Ministry of Health found that nationally, 479 districts and cities out of 491 had implemented a Jamkesda scheme or were planning to do so that year. ${ }^{46}$ Furthermore, data from the same study suggests a dramatic increase in the number of citizens covered by Jamkesda programmes. In the seventy-two districts selected by the researchers for additional analysis, membership of regional health insurance schemes rose from 8,500 people in 2006 to more than 
8 million in 2013; according to the same reference, these figures suggest an estimated membership of almost 70 million nation-wide for that year.

The rapid diffusion of Jamkesda schemes across Indonesian regions, however, should not be mistaken for policy convergence or success in improving access to healthcare. For one, wide subnational inequalities persisted in the implementation of local and national health insurance programmes. The effectiveness of the implementation of schemes such as Jamkesmas in covering low-income Indonesians varied substantially at the district level,,$^{47}$ and Jamkesda programmes themselves were often transferred from one district to another without much planning or analysis of local conditions. Many Jamkesda plans were therefore plagued with substantial implementation deficiencies such as corruption, lack of transparency in membership criteria, poor institutionalization and financial unsustainability ${ }^{48}$ Furthermore, as local governments designed the features of local health insurance programmes in complete autonomy, their diffusion allowed the emergence of specific subnational health systems featuring different levels of healthcare coverage, benefits, involvement of service providers and financing strategies. In 2010, while many Indonesian regions still struggled with sluggish progress in building more inclusive and equitable health systems, the provinces of Aceh, South Sumatra, South Sulawesi and Bali were reported as reaching UHC within their territory, thus achieving this important policy goal about nine years before the national government aims to achieve that goal in 2019.49

National policymakers showed increasing concern for such subnational inequalities in local health insurance policies and the implementation of national programmes, and thus tried to address this issue through two channels. First, to standardize and facilitate targeting procedures for Jamkesmas and other social security schemes, the Team for the Acceleration of Poverty Alleviation (TNP2K) was established in 2010 with the mandate to compile a single, integrated list of beneficiaries for all poverty alleviation programmes. ${ }^{50}$ Second, since at least 2008, the Ministry of Health and PT ASKES, the agency in charge of implementing Askeskin/Jamkesmas, repeatedly stressed the importance of local government involvement in providing health insurance solutions for low-income Indonesians. ${ }^{51}$ These efforts were formalized by the Health Minister in 2011 into a regulation, instructing that local government is responsible to cover all low-income citizens in their regions should they not be covered by Jamkesmas. ${ }^{52}$ 
Against this background, a debate emerged in policy and academic circles about the role that local governments should play in the UHC era. One view, supported by key civil society organizations and some leading academics at Gadjah Mada University in Yogyakarta, including the future Vice-Minister of Health Ali Ghufron Mukti, emphasized the desirability of local government involvement in the new system on two grounds. ${ }^{53}$ First, the potential of local government action in designing innovative policies could still be useful under UHC, allowing local governments to build on the national scheme. Second, it has been argued that local autonomy would increase government responsiveness by ensuring a better fit between policy outcomes and local-level preferences, an argument familiar to advocates of decentralized governance. Yet from a different perspective, advocated among others by Hasbullah Thabrany, a prominent health economist at the University of Indonesia, decentralized healthcare was seen as a threat to the transition to a new social security system because it was perceived to have exacerbated inequalities in access to healthcare. ${ }^{54}$ Eventually, the latter view prevailed, and plans were laid out in 2012 for a gradual merging of Jamkesda schemes into the new JKN starting from early 2014.

To summarize, local governments have played an important role in the process of healthcare reform in post-Suharto Indonesia. In the first years after the implementation of decentralization reforms in 2001, some Indonesian districts and cities designed innovative health insurance programmes aimed at increasing coverage among the poor, thereby providing concrete examples of how public policy could be used to increase access to healthcare among low-income Indonesians. In the second half of the 2000s, Jamkesda programmes spread across Indonesian regions, but their institutionalization became the source of new subnational inequalities. As national policymakers were designing the new $J K N$, they decided to tackle such new imbalances by substantially re-centralizing the financing of health insurance programmes. In the next section, I analyze in greater detail the institutional changes that allowed the unprecedented activism of local government in health policy, showing their impact on the incentives for political elites to adopt reformist social policies.

\section{Explaining Local Government Activism}

The dual process of democratization and decentralization that profoundly restructured the Indonesian state in the early 2000s 
allowed the emergence of local government as a key player in health politics, as it increased substantially the autonomy of local political elites and changed their incentives to provide broad-based social services. In this new institutional setting, in which policy responsibilities were dispersed across multiple levels of government, health policymaking was a product of a complex web of interactions between national authorities and local government officials.

\section{Decentralization and Multi-level Politics}

Two laws passed in 1999 and implemented in 2001 laid the foundations of decentralized governance in Indonesia by providing for the functioning of three levels of government, namely national, province and district/city government. Law 22/1999 describes the responsibilities of different levels of government, and it incorporates principles of regional autonomy by granting districts, cities and provinces the prerogative to govern in accordance with the preferences and priorities expressed by their constituencies. With Law 22/1999, local autonomy was extended to a wide range of areas, excluding only issues related to foreign policy, defence and security, the judicial system, fiscal and monetary policy, religion and "other issues". For health policy specifically, Article 11, Paragraph 2 of the law lists healthcare as one of the "mandatory" functions of district/city government, thus providing a legal basis for district government policy initiatives in this area. Furthermore, while decentralization laws did not grant significant fiscal powers to local government, a system of intergovernmental transfers outlined in Law 25/1999 empowered local governments with unprecedented spending capacity. General allocation funds, in particular, known in Indonesian as dana alokasi umum, are resources that local governments can allocate in complete autonomy, and could therefore be employed to finance various kinds of social programmes. As a result of these new provisions, government spending became substantially more decentralized following the entry into force of decentralization laws, and local government revenues and expenditures increasing rapidly. ${ }^{55}$

Decentralization laws thus provided the administrative and fiscal foundations for local government activism. However, health policy has been an area of shared responsibility in which various levels of government, including districts and cities, provinces, and the national government maintain substantial and overlapping prerogatives. To account for health policy outcomes in local government, it is therefore 
useful to think of the politics of health in Indonesia as an arena of interaction, cooperation, and at times confrontation among policymakers at different levels of government. One important feature of Indonesian decentralization is that the division of powers between districts and provinces has not been clearly defined, especially during the first few years of decentralized governance. The 1999 laws attribute most powers to district government, but they are vague about the prerogatives of provincial government and district-province relations. ${ }^{56}$ As a result, provinces were rather marginal actors in the first years of decentralized governance in Indonesia, in health policy as in other policy domains. In 2004, however, decentralization laws were updated with Law 32, whose Articles 13 and 14 clarify that healthcare is a mandatory government function not only for districts, but for provinces as well. This update to the decentralization laws was an important development for health policy in the regions, because it designated healthcare as an area of shared responsibility, in which both district and province government were entitled to undertake policy initiatives they considered appropriate.

For Jamkesda programmes specifically, Law 32/2004 provided the legal foundations for provincial governments to design and implement their own health insurance programmes, opening new policy spaces for cooperation between provinces and districts in this field. Indeed, in the mid- and late-2000s, some Indonesian provinces started to plan health insurance schemes in which they would co-finance district healthcare costs and work together with districts in their jurisdictions to target and socialize new multilevel health insurance plans. ${ }^{57}$ For example, in the province of Bali, after a process of negotiation between district and provincial authorities over their financial contributions, a health insurance scheme providing UHC to the province's residents was approved in 2009 and began to be implemented in 2010. ${ }^{58}$ While the features of such multi-level cooperation agreements varied substantially across regions, the involvement of provincial governments and the emergence of intergovernmental cooperation was important in tackling shortcomings of Jamkesda programmes implemented at the district level, as provincial governments, being larger administrative units, are typically endowed with larger budgets and a more professionalized workforce.

Second, the design of national health insurance schemes allowed local governments to play a crucial role in influencing policy outcomes, because the targeting and the socialization of programmes 
such as Askeskin and Jamkesmas relied heavily on input from district governments. ${ }^{59}$ Since district governments were simply granted a coverage "quota" by national policymakers, they had discretion in deciding who would qualify as a programme member, in informing their residents about benefits and claim procedures, in distributing the health cards needed to receive free treatment, and so forth. Furthermore, Jamkesmas quotas were in many districts insufficient to cover the poor population. While some poor districts received generous quotas, others were intentionally allotted a smaller quota than they needed to cover their indigent residents. ${ }^{60}$ This ensured that local governments would maintain a pivotal role in expanding access to healthcare even in the wake of large-scale intervention by national authorities.

Finally, as national efforts in this policy area gradually consolidated and became more credible, new policies from Jakarta were sometimes met with scepticism or even outright opposition in certain regions, as they were seen by some as threatening regional autonomy and the continuity of existing Jamkesda schemes. Most famously, the province of East Java and the districts of Rembang and Tangerang challenged the constitutionality of Law 40/2004 on the grounds that it violated the right of regions to choose health policies according to local needs. The resulting Constitutional Court Decision 007/PUU-III/2005, while upholding the law, clarified that local governments were entitled to design Jamkesda programmes under the $J K N$, and to complement and expand national policies as they deemed appropriate. Such developments indicate that local governments, even in the wake of large-scale national programmes, were not mere implementers of central policies. Rather, health insurance policy outcomes in Indonesia have been derived from a process of interaction and negotiation among political elites at different levels of government, a process that has been cooperative at times, while also contentious at other times.

\section{Incentives for Local Politicians and the Politics of Vertical Diffusion}

So far, I have focused on the institutional features of decentralization reforms and social policy programmes that allowed unprecedented policy autonomy and activism in healthcare policy by local governments. To understand exactly how such sweeping institutional changes relate to healthcare policy outcomes, however, we need to look more closely at the role of local political elites in Indonesia, 
and more specifically at how they have responded to the introduction of local direct elections for local leaders.

These elections, known by the Indonesian acronym pilkada, were introduced through Law 32/2004 and they have been regularly implemented since June 2005. To many Indonesian and foreign observers, pilkada elections are a crucial step towards democratic consolidation in Indonesia's regions, as they empower citizens to vote out of office elected politicians who do not perform well. ${ }^{61}$ The prospect of pilkada elections introduced new incentives for local politicians to promise, and later implement, pro-poor policies such as free healthcare programmes. While many local incumbent politicians have continued to follow old scripts of patronage politics to secure re-election in the era of direct democracy, others have invested in acquiring a reputation as "reformers" or pro-rakyat (pro-people) leaders by decisively using public policy to pursue this goal. ${ }^{62}$ For example, in an early account of pilkada elections, Priyambudi Sulistiyanto argues that the resounding electoral success in 2005 of the incumbent regent of Bantul, a district in the Special Region of Yogyakarta, was due precisely to the implementation of popular policies such as a new insurance scheme for rice and chilli farmers, free food allowances for school children, and a reform of the local clinic system that substantially improved access to healthcare for the rural poor by lowering the cost of services. ${ }^{63}$ The rapid policy diffusion process that Jamkesda schemes experienced in the late 2000 s is therefore closely intertwined with a new appreciation among local political elites that social programmes could be a very effective asset in electoral competition, and indeed free healthcare programmes have featured as prominent issues in several electoral campaigns. ${ }^{64}$

A related development that aptly illustrates the expediency of reformist social programmes in securing electoral support and fostering political careers is that a pro-rakyat reputation has, in a few cases, propelled local politicians to prominence on the national stage. Perhaps the most obvious example is that of Joko "Jokowi" Widodo, the current President of Indonesia, and Basuki Tjahaja "Ahok" Purnama, the current governor of Jakarta. These two reformminded district heads from provincial Indonesia teamed up in 2012 to form an electoral ticket and win the most coveted position in Indonesian local government, the governorship of Jakarta. One of the key elements in their successful electoral platform was the proposal of 
a health insurance programme that would cover all Jakarta residents who lacked health insurance. Since its implementation in October 2012, millions of membership cards called Kartu Jakarta Sehat (KJS, or Jakarta Health Card) have been distributed granting free access to a range of outpatient and inpatient healthcare services. In an interview with the author, Ahok observed that the KJS programme closely mirrored the policies he implemented as the head of Belitung Timur district in Sumatra, where he extended existing health insurance programmes to reach UHC well before the transition to $J K N .^{65}$ Other prominent local leaders have followed similar career paths by leveraging on the electoral appeal of "free healthcare" programmes, as they capitalized on their reputation as "pro-poor" leaders by proceeding from district heads to governors. These include Golkar heavyweights in regions outside Java, such as Alex Noerdin, former head of Musi Banyuasin district and now governor of South Sumatra, and Syahrul Yasin Limpo, former head of Gowa district and now governor of South Sulawesi. As these popular local leaders transferred the programmes they implemented in their home districts to the provincial level, Jamkesda policies thus experienced a process of "vertical" diffusion that was closely tied to new career incentives amplified by democratization and decentralization.

\section{Conclusion}

This article has investigated the process through which UHC has emerged as a key policy goal in Indonesia. While existing studies of UHC reform focus exclusively on national politics to account for reform adoption, I have analyzed the role of local governments and interactions among policymakers at different levels of government. The evidence presented here indicates that while national health insurance plans were instrumental in increasing access to healthcare in Indonesia, it was local governments that pioneered UHC in some Indonesian districts and provinces. I have argued that such developments at the local level resulted from sweeping institutional reforms that empowered local governments and changed incentives for local politicians to promise and implement pro-poor social policies. Rather than being an exclusive prerogative of national politics, the transition to UHC in Indonesia has been the product of a complex interplay between national and local policymakers at different levels of government. 
As we think about the implications of these findings for Indonesia and the comparative literature on social policy in the developing world, some important caveats should be kept in mind. First, progressive social programmes that are well-designed, adequately funded and successfully implemented are the exception rather than the rule at the level of local governments in Indonesia. On the one hand, while it is undeniable that many local governments have implemented innovative policies that have improved the condition of the most vulnerable and consolidated good governance practices, patronage politics is still widespread in local as well as national electoral politics. ${ }^{66}$ On the other hand, it is important to highlight that reformist policies such as Jamkesda schemes and similar free healthcare programmes can coexist with corruption and exclusionary implementation practices, ${ }^{67}$ and that they are often designed to provide ample discretion in service delivery. Second, this article has not delved into the expansion of access to healthcare, namely how free healthcare and UHC programmes are actually implemented, a question I have investigated elsewhere. ${ }^{68}$ To be sure, as mentioned above, there is evidence that these kinds of schemes have been successful in significantly increasing the utilization of healthcare services among the poor. However, additional research based on case-study analysis is required to ascertain the quality and the actual accessibility of the services provided, and longitudinal studies are needed to assess if higher utilization is indeed improving health outcomes. Third, this article is unable to extrapolate the applicability of these findings on Indonesia to other low and middle-income countries. Further research can investigate if, and to what degree, local government initiatives can serve as a catalyst for UHC reforms in institutional settings that are different from the one analyzed here. Finally, more attention should be devoted to the study of subnational variation in policy adoption, design, and the quality of implementation, and to identifying the drivers of divergence in local-level policy trajectories.

The case of health reform in Indonesia, however, suggests some observations about the role of local government in reforming social policy in developing countries. The first is that, in many respects, local developments in Indonesian health policy are typical of a much larger set of decentralized political systems in which the local government plays a key role in fostering social welfare, or, through inaction, in failing to do so. The uneven diffusion of healthcare reform in Indonesian local government, and the mixed record of 
Jamkesda implementation, are an apt illustration that decentralized governance can have contrasting outcomes, and that local-level factors may be crucial in moderating the effect of radical institutional reforms implemented at the national level. More specifically, the case analyzed here indicates that the policy outcomes associated with democratization can vary dramatically at the subnational level. Second, with regard to the debate on UHC specifically, the Indonesian case suggests that innovative policies implemented by local governments might have a transformative impact on the lives of many by substantially reducing the costs of healthcare. As discussed, the generalizability of this model and its sustainability should be further investigated, but in the several years where a large proportion of poor Indonesians lacked adequate health insurance coverage, support from the local government was an important factor in encouraging them to seek health counselling and treatment. Moving towards UHC can be a long and difficult process in low and middle-income countries, and local government initiatives can tackle the imbalances and the uncertainties associated with such transitions. Finally, this article has highlighted the importance of local elites and electoral incentives for social policy in recently democratized countries. While Indonesian activists and civil society organizations may be growing increasingly assertive in Indonesian politics, bottom-up mobilization was a marginal factor in the proliferation of Jamkesda programmes. Rather, it was the top-down, opportunistic, electorally motivated exploitation of slogans such as "free healthcare" and "health for the people" by local politicians that drove the rapid expansion of regional health insurance schemes.

The road to making quality healthcare services accessible for all in Indonesia and neighbouring countries in Southeast Asia is still long and uncertain. As national governments devise policies to approach this goal, a synergy among a wide range of stakeholders such as politicians, bureaucrats, civil society organizations, service providers and pharmaceutical companies is crucial. The Indonesian case shows that local governments can be one of several key actors in reforming healthcare by catering to the preferences of local communities, but it also shows that increased local autonomy can widen subnational inequalities. Deciding how to solve the tension between policy responsiveness and inequality is an essentially political choice, one that all diverse, decentralized nations such as Indonesia should discuss transparently and exhaustively. 


\section{NOTES}

1 Gilbert Abotisem Abiiro and Manuela De Allegri, "Universal Health Coverage from Multiple Perspectives: A Synthesis of Conceptual Literature and Global Debates", BMC International Health and Human Rights 15, no. 17 (July 2015): 1-7; World Health Organization, Health Systems Financing: The Path to Universal Coverage (Geneva, Switzerland: World Health Organization, 2010).

2 Gary King, Emmanuela Gakidou, Kosuke Imai, Jason Lakin, Ryan T. Moore, Clayton Nall, Nirmala Ravishankar, Manett Vargas, Martha María Téllez-Rojo and Juan Eugenio Hernández Ávila, "Public Policy for the Poor? A Randomised Assessment of the Mexican Universal Health Insurance Programme", The Lancet 373, no. 9673 (April 2009): 1447-54; Adam D. Koon and Susannah H. Mayhew, "Strengthening the Health Workforce and Rolling out Universal Health Coverage: The Need for Policy Analysis", Global Health Action 6, no. 21852 (July 2013): 1-2; Joseph Kutzin, "Health Financing for Universal Coverage and Health System Performance: Concepts and Implications for Policy”, Bulletin of the World Health Organization 91, no. 8 (August 2013): 602-11.

3 Scott L. Greer and Claudio A. Méndez, "Universal Health Coverage: A Political Struggle and Governance Challenge”, American Journal of Public Health 105, no. 5 (November 2015): 637-39.

4 Gøsta Esping-Andersen, The Three Worlds of Welfare Capitalism (Princeton, New Jersey: Princeton University Press, 1990); Walter Korpi, "Power, Politics, and State Autonomy in the Development of Social Citizenship: Social Rights During Sickness in Eighteen OECD Countries since 1930”, American Sociological Review (June 1989): 309-28.

5 Richard Sandbrook, Marc Edelman, Patrick Heller and Judith Teichman, Social Democracy in the Global Periphery: Origins, Challenges, Prospects (New York: Cambridge University Press, 2007).

$6 \quad$ A. Hicken, "Clientelism”, Annual Review of Political Science 14 (June 2011): 289-310; Herbert Kitschelt and Steven I. Wilkinson, eds., Patrons, Clients and Policies: Patterns of Democratic Accountability and Political Competition (New York: Cambridge University Press, 2007).

7 Stephan Haggard and Robert R. Kaufman, Development, Democracy, and Welfare States: Latin America, East Asia, and Eastern Europe (Princeton, New Jersey: Princeton University Press, 2008); Illan Nam, Democratizing Health Care: Welfare State Building in Korea and Thailand (New York: Palgrave Macmillan, 2015); Joseph Wong, Healthy Democracies: Welfare Politics in Taiwan and South Korea (Ithaca, New York: Cornell University Press, 2004).

$8 \quad$ I refer to "democratization" as the process of transitioning from an authoritarian to a democratic political regime.

9 Throughout the article I use the term "regions" as the term daerah is typically used in Bahasa Indonesia, which is to refer indiscriminately to various types of local government institutions, including provinces, cities and districts.

10 Esping-Andersen, The Three Worlds of Welfare Capitalism, op. cit.; Alexander M. Hicks, Social Democracy and Welfare Capitalism: A Century of Income Security Politics (Ithaca, New York: Cornell University Press, 1999); Korpi, "Power, Politics, and State Autonomy in the Development of Social Citizenship", op. cit. 
11 Evelyne Huber and John D. Stephens, Democracy and the Left: Social Policy and Inequality in Latin America (Chicago, Illinois: University of Chicago Press, 2012); Patrick Heller, The Labor of Development: Workers and the Transformation of Capitalism in Kerala, India (Ithaca, New York: Cornell University Press, 1999); Atul Kohli, The State and Poverty in India: The Politics of Reform (New York: Cambridge University Press, 1987); Deborah Bräutigam, "Institutions, Economic Reform, and Democratic Consolidation in Mauritius", Comparative Politics 30, no. 1 (October 1997): 45-62; Richard Sandbrook, "Origins of the Democratic Developmental State: Interrogating Mauritius", Canadian Journal of African Studies 39, no. 3 (2005): 549-81.

Jennifer Pribble, Welfare and Party Politics in Latin America (New York: Cambridge University Press, 2013); Kurt Weyland, Raúl L. Madrid and Wendy Hunter, eds., Leftist Governments in Latin America: Successes and Shortcomings (New York: Cambridge University Press, 2010).

${ }_{13}$ Teri L. Caraway, Michele Ford and Hari Nugroho, "Translating Membership into Power at the Ballot Box? Trade Union Candidates and Worker Voting Patterns in Indonesia's National Elections”, Democratization 22, no. 7 (2015): 1296-316.

Geof Wood and Ian Gough, "A Comparative Welfare Regime Approach to Global Social Policy”, World Development 34, no. 10 (October 2006): 1696-712.

15 Philip Keefer and Stuti Khemani, "Democracy, Public Expenditures, and the Poor: Understanding Political Incentives for Providing Public Services", World Bank Research Observer 20, no. 1 (Spring 2005): 1-27.

Barbara Geddes, "A Game Theoretic Model of Reform in Latin American Democracies”, American Political Science Review 85, no. 2 (1991): 371-92.

17 Kurt Weyland, "Social Movements and the State: The Politics of Health Reform in Brazil”, World Development 23, no. 10 (October 1995): 1699-712.

Kitschelt and Wilkinson, Patterns of Democratic Accountability and Political Competition, op. cit.; Susan C. Stokes, "Perverse Accountability: A Formal Model of Machine Politics with Evidence from Argentina", American Political Science Review 99, no. 3 (August 2005): 315-25.

Anies Rasyid Baswedan, "Political Islam in Indonesia: Present and Future Trajectory”, Asian Survey 44, no. 5 (October 2004): 669-90.

20 Edward Aspinall and Mada Sukmajati, eds., Electoral Dynamics in Indonesia: Money Politics, Patronage and Clientelism at the Grassroots (Singapore: NUS Press, 2016); Marcus Mietzner, "Party Financing in Post-Soeharto Indonesia: Between State Subsidies and Political Corruption", Contemporary Southeast Asia 29, no. 2 (August 2007): 238-63.

21 To be sure, democratization is only one of the many ways in which institutions can shape social policy and health policy in particular. See Joel Sawat Selway, "Electoral Reform and Public Policy Outcomes in Thailand: The Politics of the 30-Baht Health Scheme”, World Politics 63, no. 1 (January 2011): 165-202; Jennifer Pribble, "Universalizing Healthcare Policy in Chile and Uruguay", paper presented at the APSA 2010 Annual Meeting, Washington, D.C., 2010.

David S. Brown and Wendy Hunter, "Democracy and Social Spending in Latin America, 1980-92", American Political Science Review 93, no. 4 (December 1999): 779-90; Timothy Besley and Masayuki Kudamatsu, "Health and Democracy”, The American Economic Review 96, no. 2 (May 2006): 313-18; 
Masayuki Kudamatsu, "Has Democratization Reduced Infant Mortality in Sub-Saharan Africa? Evidence from Micro Data", Journal of the European Economic Association 10, no. 6 (December 2012): 1294-317.

Amartya Sen, Development as Freedom (Oxford, UK: Oxford University Press, 2001).

$24 \quad$ Robin Harding and David Stasavage, "What Democracy Does (and Doesn't Do) for Basic Services: School Fees, School Inputs, and African Elections", The Journal of Politics 76, no. 1 (January 2014): 229-45; David A. Lake and Matthew A. Baum, "The Invisible Hand of Democracy Political Control and the Provision of Public Services", Comparative Political Studies 34, no. 6 (June 2001): 587-621.

Monika Dowbor and Peter P. Houtzager, "The Role of Professionals in Policy Reform: Cases from the City Level, São Paulo", Latin American Politics and Society 56, no. 3 (Fall 2014): 141-62; Joseph Harris, “'Developmental Capture' of the State: Explaining Thailand's Universal Coverage Policy”, Journal of Health Politics Policy and Law 40, no. 1 (February 2015): 165-93; Sripen Tantivess and Gill Walt, "The Role of State and Non-State Actors in the Policy Process: The Contribution of Policy Networks to the Scale-up of Antiretroviral Therapy in Thailand", Health Policy and Planning 23, no. 5 (September 2008): 328-38; Nam, Democratizing Health Care, op. cit.

Nancy Bermeo, “Does Electoral Democracy Boost Economic Equality?”, Journal of Democracy 20, no. 4 (October 2009): 21-35; Joan M. Nelson, "Elections, Democracy, and Social Services", Studies in Comparative International Development 41, no. 4 (Winter 2007): 79-97.

Haggard and Kaufman, Development, Democracy, and Welfare States, op. cit.; Nam, Democratizing Health Care, op. cit.; Wong, Healthy Democracies, op. cit. Edward Aspinall, "Health Care and Democratization in Indonesia", Democratization 21, no. 5 (2014): 803-23.

Asep Yadi Suryahadi, Vita Febriany and Athia Yumna, Expanding Social Security in Indonesia: The Processes and Challenges (Geneva: United Nations Research Institute for Social Development, 2014).

Golkar, Orde Baru Dalam Angka, 1969-1991: Hasil-Hasil Pembangunan Jangka Panjang Tahap Pertama [New Order in Numbers, 1969-1991: Results of Longterm Development Step One] (Jakarta: Golongan Karya, Dewan Pimpinan Pusat, Sekretariat Jenderal, 1992), p. 154.

Anne Booth, "Decentralisation and Poverty Alleviation in Indonesia", Environment and Planning C: Government and Policy 21, no. 2 (April 2003): 181-202.

Emir Soendoro, Jaminan Sosial Solusi Bangsa Indonesia Berdikari [Social Security Solutions for the Resilience of Indonesian People] (Jakarta: PT DInov ProGRESS Indonesia, 2009), pp. 98-99.

Robert Sparrow, "Targeting the Poor in Times of Crisis: The Indonesian Health Card”, Health Policy and Planning 23, no. 3 (March 2008): 189-90.

Sudarno Sumarto, Asep Suryahadi and Wenefrida Widyanti, "Designs and Implementation of the Indonesian Social Safety Net Programs", The Developing Economies 40, no. 1 (March 2002): 3-31. 
35 Pandu Harimurti, Eko Pambudi, Anna Pigazzini and Ajay Tandon, "The Nuts \& Bolts of Jamkesmas, Indonesia's Government-Financed Health Coverage Program for the Poor and Near-Poor", in Universal Health Coverage (UNICO) Studies Series (Washington, D.C.: The World Bank, 2013); Yogi Vidyattama, Riyana Miranti and Budy P. Resosudarmo, "The Role of Health Insurance Membership in Health Service Utilisation in Indonesia", Bulletin of Indonesian Economic Studies 50, no. 3 (December 2014): 393-413; World Bank, Jamkesmas Health Service Fee Waiver: Social Assistance Program and Public Expenditure Review 4 (Jakarta: The World Bank, Indonesia Office, 2012).

See Dinna Wisnu, Politik Sistem Jaminan Sosial: Menciptakan Rasa Aman Dalam Ekonomi Pasar [The Politics of the Social Security System: Creating a Feeling of Security in the Market Economy] (Jakarta: PT Gramedia Pustaka Utama, 2012).

${ }^{37}$ Sulastomo, Sistem Jaminan Sosial Nasional: Mewujudkan Amanat Konstitusi [The National Social Security System: Realizing the Constitutional Mandate] (Jakarta: Kompas Penerbit Buku, 2011).

Hans Antlöv, "Village Leaders and the New Order", in Leadership on Java: Gentle Hints, Authoritarian Rule, edited by Hans Antlöv and Sven Cederroth (London: Routledge, 1995), pp. 73-96.

Januar Achmad, Hollow Development: The Politics of Health in Soeharto's Indonesia (Canberra: Australian National University, 1999), pp. 32-33.

Vedi R. Hadiz, "Decentralization and Democracy in Indonesia: A Critique of Neo-Institutionalist Perspectives", Development and Change 35, no. 4 (September 2004): 697-718. Indeed, while the distinction between reform and clientelism may be a useful analytical dichotomy, the practice of Indonesian local politics shows a much more nuanced reality, as these two ideal-types often overlap and intermingle. Throughout the text, I use the terms "innovative" or "reformist" to describe policies that show potential for increasing the inclusiveness and the transparency of local health systems. However, it should be emphasized that the adoption of such policies should not necessarily be interpreted as a sign of civic-minded leadership, or as a decisive break from clientelistic practices.

${ }_{41}$ World Bank, Nine Case Studies from Indonesia: Making Services Work for the Poor (Jakarta: The World Bank, Indonesia Poverty Analysis Program, 2006); Aspinall, "Health Care and Democratization in Indonesia", op. cit.; Edward Aspinall and Eve Warburton, "A Healthcare Revolution in the Regions", Inside Indonesia 111 (January 2013).

42 Ascobat Gani, Hasbullah Thabrany, Pujianto, Ferry Yanuar, Tata Tachman, Adiatma Siregar, Hudi K. Wahyu, Susilo Soerachmad, Widyastuti, Yulherina, Nurbaiti and David W. Dunlop, Report on Assessment of Health Financing System in Selected Districts and Municipalities (Depok, Indonesia: Center for Health Economics and Policy Studies, School of Public Health, University of Indonesia, 2008). As I show in a related work, policy innovation in these "pioneer" districts is closely related to broader patterns of state capacity and democratic accountability at the local level, as early reformers display higher levels of civic engagement and overall institutional performance. Diego Fossati, "Beyond 'Good Governance': The Multi-Level Politics of Health Insurance for the Poor in Indonesia”, World Development 87 (November 2016): 291-306. 
${ }^{43}$ Robert Sparrow, Sri Budiyati, Athia Yumna, Nila Warda, Asep Suryahadi and Arjun S. Bedi, "Sub-National Health Care Financing Reforms in Indonesia", Health Policy and Planning (forthcoming); Adenantera Dwicaksono, Ari Nurman and Panji Yudha Prasetya, Jamkesmas and District Health Care Insurance Schemes: Assessment Resports from 8 Districts/Municipalities and 2 Provinces (Bandung, Indonesia: Perkumpulan INISIATIF, 2012).

44 See Andrew Rosser and Ian Wilson, "Democratic Decentralisation and ProPoor Policy Reform in Indonesia: The Politics of Health Insurance for the Poor in Jembrana and Tabanan", Asian Journal of Social Science 40, nos. 5-6 (2012): 608-34. Other instances include cases in Java such as Purbalingga and Yogyakarta, where local health insurance schemes were implemented in the early 2000s, and regions in the outer islands such as Banjar in Kalimantan, Bantaeng in Sulawesi and Palembang in Sumatra. Hastuti, Syaikhu Usman, M. Sulton Mawardi, Justin Sodo, Deswanto Marbun and Ruhmaniyati, The Role of Social Protection Programs in Reducing the Impact of the Global Financial Crisis 2008/2009 (Jakarta: SMERU, 2010); Dwicaksono, Nurman, and Prasetya, Jamkesmas and District Health Care Insurance Schemes, op. cit.; Arif Rahman Hakim, "Pelayanan Pengobatan Gratis Di Kabupaten Bantaeng" [Free Healthcare Service in Bantaeng District], Kompasiana.com, 27 July 2012, available at <http://www.kompasiana.com/arifhakim/pelayanan-pengobatan-gratis-dikabupaten-bantaeng_55127c76813311dd56bc60d9>.

$45 \quad$ Elizabeth Pisani, Maarten Olivier Kok and Kharisma Nugroho, “Indonesia's Road to Universal Health Coverage: A Political Journey", Health Policy and Planning (forthcoming).

46 Hasbullah Thabrany, Kurnia Sari, Robert Tilden, David W. Dunlop and Yuniar Hajaraeni, Supporting Indonesia's DJSN to Develop National Guidelines for Implementing a National Social Health Insurance Program by 2014 (Depok, Indonesia: Center for Health Economics and Policy Studies, School of Public Health, University of Indonesia, 2015), p. 20.

47 Diego Fossati, "Is Indonesian Local Government Accountable to the Poor? Evidence from Health Policy Implementation", Journal of East Asian Studies 16, no. 3 (November 2016): 307-30.

Yatimul Ainun, “Jamkesda Distop, Warga Miskin 'Dilarang' Sakit Jamkesda” [Terminated, the Poor are 'Forbidden' to Fall Sick], Kompas.com, 6 July 2012, available at <http://regional.kompas.com/read/2012/07/06/13394571/Jamkesda. Distop.Warga.Miskin.Dilarang.Sakit>; Taufiq Fatkhurrohman, "Enam Kabupaten/ Kota Di Jatim Belum Bayar Jamkesda - Six Districts/Cities in East Java Have Not Yet Paid Jamkesda", Tempo.co, 13 July 2012, available at <http://nasional. tempo.co/read/news/2012/07/13/058416804/enam-kabupaten-kota-di-jatim-belumbayar-jamkesda>; "Kartu Jamkesda Pun Diperjualbelikan Hingga Rp 2 Juta Jamkesda Cards Being Sold and Bought for Up to 2 Million IDR”, Kompas.com, 6 April 2011, available at <http://health.kompas.com/read/2011/04/06/06244725/ Kartu.Jamkesda.Pun.Diperjualbelikan.hingga.Rp.2.Juta>.

49 Departemen Kesehatan R.I., Profil Kesehatan Indonesia 2010 [Indonesia Health Profile 2010] (Jakarta: Departemen Kesehatan RI, 2011).

50 Sudarno Sumarto and Samuel Bazzi, "Social Protection in Indonesia: Past Experiences and Lessons for the Future”, paper presented at the 2011 Annual Bank Conference on Development Opportunities (ABCDE) jointly organized by 
the World Bank and OECD, Paris, 30 May-1 June 2011. As I discuss in the next section, Askeskin and Jamkesmas relied on local government officials to identify programme beneficiaries.

Thabrany et al., Supporting Indonesia's DJSN to Develop National Guidelines for Implementing a National Social Health Insurance Program by 2014, op. cit., p. 185.

Peraturan Menteri Kesehatan Republik Indonesian No. 903/MENKES/PER/V/2011.

Ali Ghufron Mukti and Moertjahjo, Sistem Jaminan Kesehatan: Konsep Desentralisasi Terintegrasi [Health Insurance System: The Concept of Integrated Decentralisation] (Yogyakarta: Magister Kebijakan Pembiayaan dan Manajemen Asuransi Kesehatan, Fakultas Kedokteran, Universitas Gadjah Mada bekerja sama dengan Asosiasi Jaminan Sosial Daerah, 2008); Dwicaksono, Nurman, and Prasetya, Jamkesmas and District Health Care Insurance Schemes, op. cit.

Hasbullah Thabrany, "Politics of National Health Insurance of Indonesia: A New Era of Universal Coverage", paper presented at the 7th European Conference on Health Economics, Rome, 2008, p. 5.

Blane D. Lewis, "Twelve Years of Fiscal Decentralization: A Balance Sheet”, in Regional Dynamics in a Decentralized Indonesia, edited by Hal Hill (Singapore: Institute of Southeast Asian Studies, 2014), p. 138.

One plausible reason why most powers were attributed to district rather than provincial government is that decentralization laws were promulgated at a time of increasing separatist tensions, and a fully federalist model of governance empowering provinces was seen by many as a threat to national unity. See Richard Seymour and Sarah Turner, "Otonomi Daerah: Indonesia's Decentralisation Experiment", New Zealand Journal of Asian Studies 4, no. 2 (December 2002): 37.

Fossati, "Beyond 'Good Governance”, op. cit.

Author interview with the Head of Health Department, Province of Bali, Denpasar, Bali, 16 January 2014.

Rahayu Sri Lestari and Evi Subardi, Bantuan Sosial Di Indonesia Sekarang Dan Ke Depan: BOS, Jamkesmas, PNPM Mandiri, PKH [Social Policy in Indonesia Now and in the Future: BOS, Jamkesmas, PNPM Mandiri, PKH] (Bandung, Indonesia: Fokusmedia, 2012), p. 36.

The reason, according to TNP2K officials interviewed by the author in January 2014 in Jakarta, was that local governments, especially in regions deemed to be "fiscally strong" (i.e. where revenues other than intergovernmental transfers were substantial), were expected to contribute to the expansion of access to healthcare with their own resources.

61 Maribeth Erb and Priyambudi Sulistiyanto, "Indonesia and the Quest for 'Democracy'”, in Deepening Democracy in Indonesia? Direct Elections for Local Leaders (Pilkada), edited by Maribeth Erb and Priyambudi Sulistiyanto (Singapore: Institute of Southeast Asian Studies, 2009), pp. 1-37.

Explaining variation in such electoral strategies is a crucial endeavour for research on Indonesian local politics. Various factors, such as the configuration of local patronage networks, historical legacies and the nature of electoral competition may affect the demand for healthcare reform and incumbents' propensity to adopt it. In a related paper, I tackle this question by analyzing 
the quality of implementation of health insurance programmes, and I find that the competitiveness of local politics is an important determinant of policy outcomes. See Fossati, "Is Indonesian Local Government Accountable to the Poor?", op. cit. This suggests that the effect of pilkada elections in improving access to healthcare has varied significantly across districts.

Priyambudi Sulistiyanto, "Pilkada in Bantul District: Incumbent, Populism and the Decline of Royal Power", in Deepening Democracy in Indonesia? Direct Elections for Local Leaders (Pilkada), op. cit., pp. 190-209. Aspinall, "Health Care and Democratization in Indonesia”, op. cit., pp. 814-15. Author interview with Basuki Tjahaja Purnama, Jakarta, 25 July 2013. Aspinall and Sukmajati, Electoral Dynamics in Indonesia, op. cit. Andrew Rosser, "Realising Free Health Care for the Poor in Indonesia: The Politics of Illegal Fees”, Journal of Contemporary Asia 42, no. 2 (May 2012): 255-75.

68 Fossati, "Beyond 'Good Governance”, op. cit. 